\title{
A giant aneurysm of the left main coronary artery and anomalous origin of the right coronary artery
}

\author{
Hakan Özkan ${ }^{1}$, Ahmet Seçkin Çetinkaya ${ }^{1}$, Gökhan Ertaş² \\ ${ }^{1}$ Department of Cardiology, Medicine Faculty, Bahçeşehir University, İstanbul, Turkey \\ ${ }^{2}$ Department of Cardiology, İstanbul Dr. Siyami Ersek Thoracic and Cardiovascular Surgery Training \\ and Research Hospital, İstanbul, Turkey
}

Kardiochirurgia i Torakochirurgia Polska 2015; 12 (1): 80-82

\begin{abstract}
We report a rare case of a giant aneurysm of the left main coronary artery (LMCA) and anomalous origin of the right coronary artery (RCA) from the left ventricle presented with chest pain.
\end{abstract}

Key words: giant aneurysm, left main coronary artery.

A 39-year-old woman presented with chest pain and palpitation. Cardiac examination revealed 3/6 midsystolic murmur and early diastolic murmur. All laboratory values were unremarkable. Transthoracic echocardiography revealed aortic stenosis with $26 \mathrm{mmHg}$ mean gradient and diastolic flow near the aortic valve suggesting a coronary anomaly arising from the left ventricle (Fig. 1A). Transesophageal echocardiography demonstrated a giant left main coronary artery (LMCA) and anomalous origin of the right coronary artery (RCA) from the left ventricle (Fig. 1B). Multislice computed tomography (CT) indicated a giant left coronary artery aneurysm (Fig. 2). Coronary angiography was performed to show the coronary anatomy. The left coronary angiogram demonstrated a giant LMCA and a dilated proximal left anterior descending artery (LAD) and circumflex artery (CX) with the tortuous collateral vessel to the RCA (Fig. 3). Surgery for the fistula and coronary artery aneurysm was planned but the patient refused the surgery.

Giant coronary artery aneurysms with fistula are rare lesions [1]. The incidence of a giant coronary artery aneurysm has been reported to be $0.02 \%$, however aneurysms with congenital coronary artery fistulas have been reported at an incidence of 5.9\% [2]. Atherosclerosis, Kawasaki disease, congenital, inflammatory disorders, drugs and infectious etiologies have been associated with coronary artery aneurysms. Atherosclerosis is the most common

\section{Streszczenie}

W pracy przedstawiono rzadki przypadek olbrzymiego tętniaka w pniu lewej tętnicy wieńcowej oraz nieprawidłowego odejścia prawej tętnicy wieńcowej od lewej komory u pacjenta zgłaszającego ból klatki piersiowej.

Słowa kluczowe: olbrzymi tętniak, pień lewej tętnicy wieńcowej.

cause of the coronary artery aneurysm in adults, while Kawasaki disease is the most common cause of the coronary artery aneurysm in childhood [3]. Angina, heart failure, endocarditis, arrhythmias or myocardial ischemia might occur due to the coronary steal. Most of the patients are asymptomatic, and giant coronary aneurysms are incidentally found during diagnostic imaging modalities [4]. The differential diagnosis of a giant coronary aneurysm includes mediastinal masses, aneurysm of the ventricle, pseudoaneurysm of the ascending aorta or the pulmonary trunk. The coronary artery aneurysm may be associated with coronary anomalies, particularly in the anomalous origin of the RCA from the pulmonary artery or the anomalous origin of the left coronary artery from the pulmonary artery (ALCAPA syndrome). There are no controlled randomized trials to evaluate optimal therapy for coronary artery aneurysms. Therefore, coronary artery aneurysms are usually medically followed, however in some cases, the surgery is mandatory to prevent a coronary rupture and cardiac tamponade [5].

In conclusion, we report a rare case of a giant aneurysm of the LMCA and anomalous origin of the RCA from the left ventricle presented with chest pain. The appropriate treatment for coronary artery aneurysms is controversial, however treatment should be planned depending on the clinical situation. 

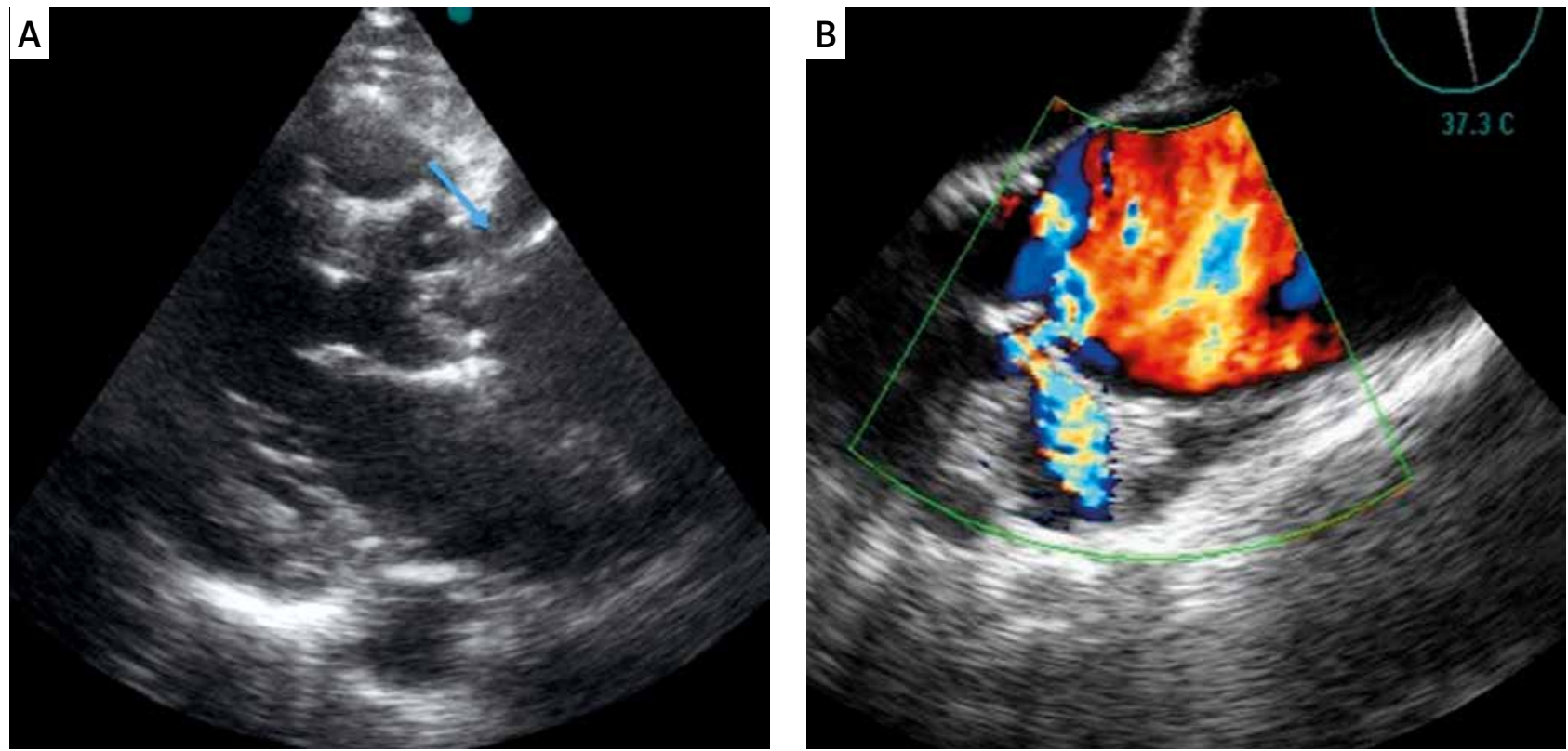

Fig. 1. Transthoracic echocardiography (A) and transesophageal echocardiography (B) demonstrated a giant left main coronary artery and anomalous origin of the right coronary artery (arrow)
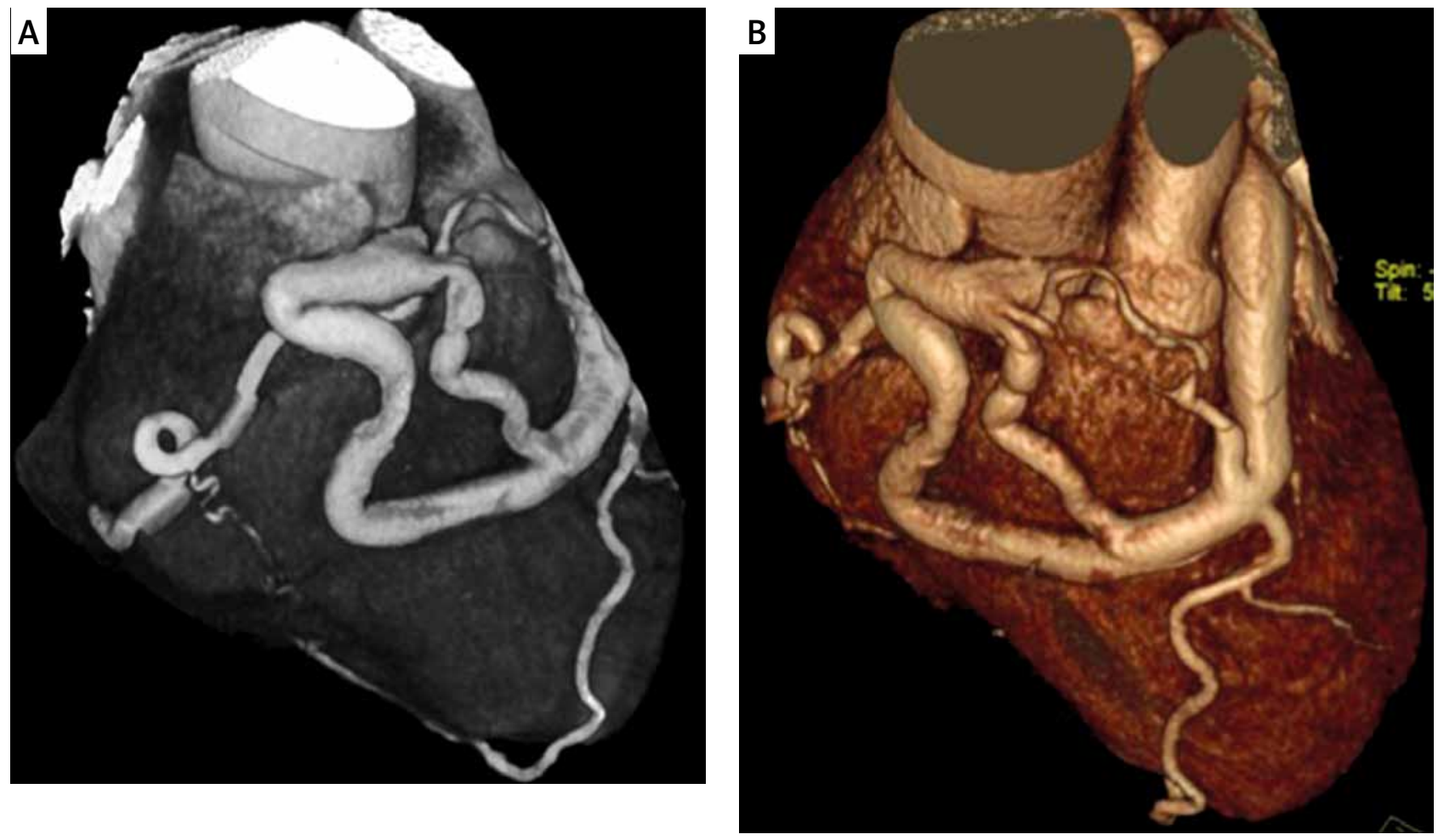

Fig. 2. Multislice computed tomography revealed a giant left coronary artery aneurysm 

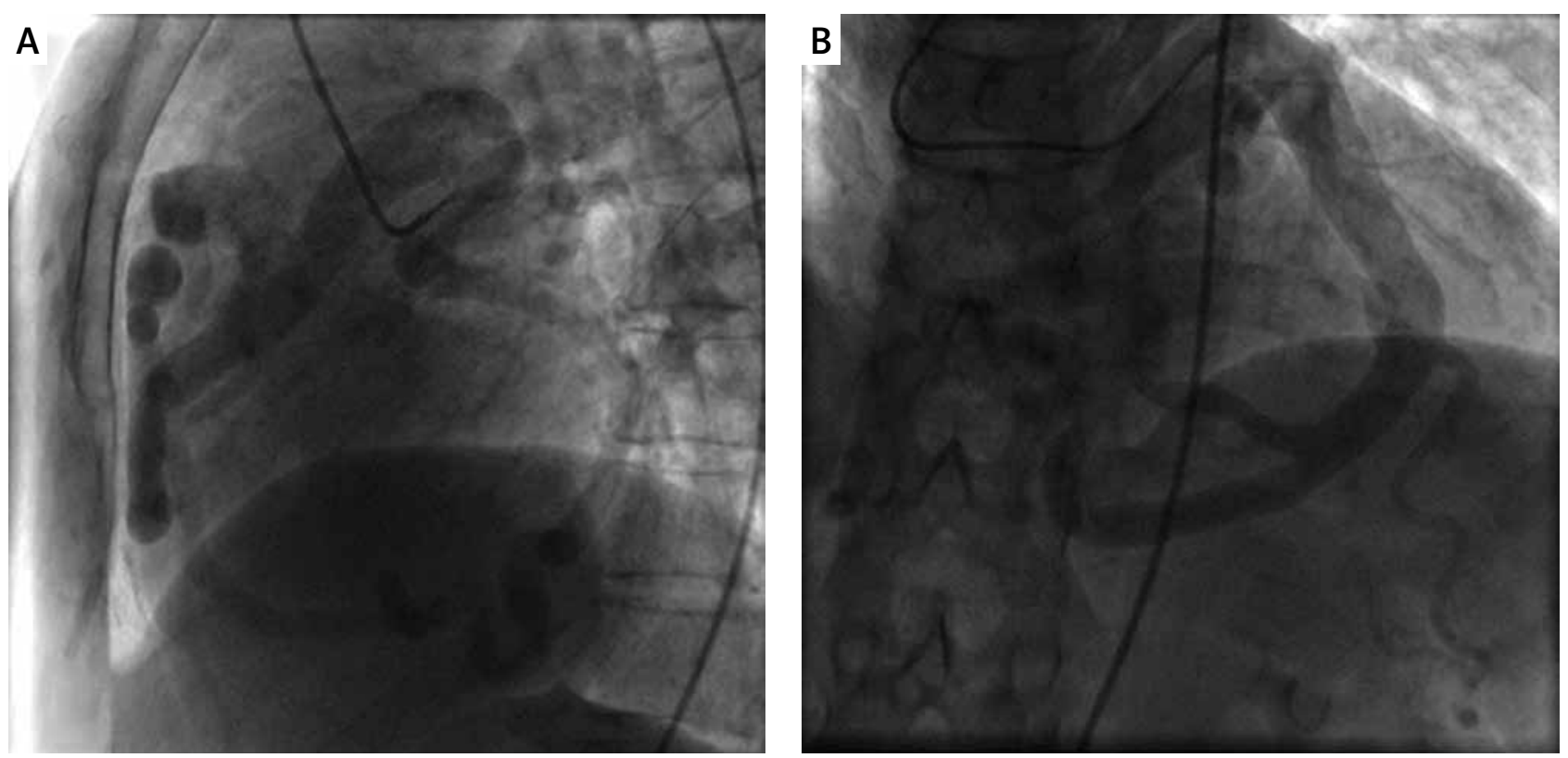

Fig. 3. Left coronary angiogram demonstrated a giant left coronary artery aneurysm

\section{Disclosure}

Authors report no conflict of interest.

\section{References}

1. Morita H, Ozawa H, Yamazaki S, Yamauchi Y, Tsuji M, Katsumata T, Ishizaka N. A case of giant coronary artery aneurysm with fistulous connection to the pulmonary artery: a case report and review of the literature. Intern Med 2012; 51: 1361-1366.

2. Li D, Wu Q, Sun L, Song Y, Wang W, Pan S, Luo G, Liu Y, Qi Z, Tao T, Sun JZ, Hu S. Surgical treatment of giant coronary artery aneurysm. J Thorac Cardiovasc Surg 2005; 130: 817-821.

3. Antoniadis AP, Chatzizisis YS, Giannoglou GD. Pathogenetic mechanisms of coronary ectasia. Int J Cardiol 2008; 130: 335-343.

4. Lee SY, Park YH, Yeo HJ, Sohn CB, Han DC, Kim JS, Kim J, Kim JH, Chun KJ. Congenital giant right coronary artery aneurysm with fistula to the coronary sinus and persistent left superior vena cava in an old woman. Korean Circ J 2012; 42: 792-795.

5. İzgi A, Kırma C, Türkmen M, Tanalp AC. Successful coil embolization of a large coronary artery fistula in a patient with congestive heart failure. Türk Kardiyol Dern Arş 2006; 34: 47-50. 